\title{
Pectin, a versatile polysaccharide present in plant cell walls
}

\author{
Alphons G. J. Voragen · Gerd-Jan Coenen • \\ René P. Verhoef · Henk A. Schols
}

Received: 9 February 2009/ Accepted: 18 February 2009/Published online: 13 March 2009

(c) The Author(s) 2009. This article is published with open access at Springerlink.com

\begin{abstract}
Pectin or pectic substances are collective names for a group of closely associated polysaccharides present in plant cell walls where they contribute to complex physiological processes like cell growth and cell differentiation and so determine the integrity and rigidity of plant tissue. They also play an important role in the defence mechanisms against plant pathogens and wounding. As constituents of plant cell walls and due to their anionic nature, pectic polysaccharides are considered to be involved in the regulation of ion transport, the porosity of the walls and in this way in the control of the permeability of the walls for enzymes. They also determine the water holding capacity. The amount and composition of pectic molecules in fruits and vegetables and other plant produce strongly determine quality parameters of fresh and processed food products. Pectin is also extracted from suitable agro-by-products like citrus peel and apple pomace and used in the food industry as natural ingredients for their gelling, thickening, and stabilizing properties. Some pectins gain more and more interest for their health modulating activities. Endogenous as well as exogenous enzymes play an important role in determining the pectic structures present in plant tissue, food products, or ingredients at a given time. In this paper functional and structural characteristics of pectin are described with special emphasis on the structural elements making up the pectin molecule, their interconnections and present models which envisage the accommodation of all structural elements in a
\end{abstract}

\footnotetext{
A. G. J. Voragen $(\bowtie) \cdot$ G.-J. Coenen · R. P. Verhoef ·

H. A. Schols

Laboratory of Food Chemistry, Department of Agrotechnology and Food Sciences, Wageningen University, P.O. Box 8129, 6700 EV Wageningen, The Netherlands

e-mail: fons.voragen@wur.nl
}

macromolecule. Attention is also given to analytical methods to study the pectin structure including the use of enzymes as analytical tools.

Keywords Pectin - Chemical structure .

Structure elucidation · Enzymes · Functionalities

\section{Pectin}

Pectin is one of the major plant cell wall components and probably the most complex macromolecule in nature, as it can be composed out of as many as 17 different monosaccharides containing more than 20 different linkages [1-3].

\section{Plant functionality of pectin}

In a plant, pectin is present in the middle lamella, primary cell and secondary walls and is deposited in the early stages of growth during cell expansion [4]. Its functionality to a plant is quite divers. First, pectin plays an important role in the formation of higher plant cell walls [5], which lend strength and support to a plant and yet are very dynamic structures [4]. In general, the polymeric composition of primary cell walls in dicotyledonous plants consists of approximately $35 \%$ pectin, $30 \%$ cellulose, $30 \%$ hemicellulose, and $5 \%$ protein [5]. Grasses contain $2-10 \%$ pectin and wood tissue ca $5 \%$. In cell walls of some fruits and vegetables, the pectin content can be substantially higher and the protein content lower [6]. Second, pectin influences various cell wall properties such as porosity, surface charge, $\mathrm{pH}$, and ion balance and therefore is of importance to the ion transport in the cell wall [7]. Furthermore, pectin oligosaccharides are known to activate plant defense 
responses: they elicit the accumulation of phytoalexin which has a wide spectrum of anti-microbial activity [810]. Finally, pectin oligosaccharides induce lignification [11] and accumulation of protease inhibitors [12] in plant tissues.

\section{Pectin as food ingredient}

Pectin is used in foods mainly as gelling, stabilizing, or thickening agent in products such as jam, yoghurt drinks, fruity milk drinks, and ice cream [13]. Most of the pectin used by food industry originates from citrus or apple peel from which it is extracted at low $\mathrm{pH}$ and high temperature and is primarily a homogalacturonan [14]. In products that naturally contain pectin, e.g., fruit and vegetables, important quality changes during storage and processing are related to changes in pectin structure. Native or added pectic enzymes can play an important role in these changes [15].

\section{Health aspects of pectins}

Plant products, fresh, extracted or processed, constitute a large part of the human diet. As a fiber naturally present in these food products, pectic substances fulfill a nutritional function [16, 17]. Next to its nutritional status, pectin increasingly gains interest as a possible health promoting polysaccharide and several studies have been conducted to prove its health promoting function. One study showed the beneficial influence of vegetable pectin-chamomile extract on shortening the course of unspecific diarrhea and relieving associated symptoms [18]. Another study revealed that carrot soup contains pectin derived oligosaccharides that block the adherence of various pathogenic micro-organisms to the intestinal mucosa in vitro, which is an important initial step in the pathogenesis of gastrointestinal infections [19, 20]. Furthermore, pectins were shown to have immuno-regulatory effects in the intestine, to change the ileal microbial activity, to change the morphology of the small intestinal wall $[21,22]$, to lower the blood cholesterol level [23-25], and to slow down the absorption of glucose in the serum of diabetic and obese patients [25-27]. To better understand the bio-functionality of pectic polysaccharides scientific elucidation of the structures responsible for the beneficial effect is very important [28].

\section{Pectin structural elements}

Pectin is defined as a hetero-polysaccharide predominantly containing galacturonic acid (GalA) residues, in which varying proportions of the acid groups are present as methoxyl esters, while a certain amount of neutral sugars might be present as side chains [29]. De Vries [30] recognized a pattern of "smooth" homogalacturonic regions and ramified "hairy" regions, in which most of the neutral sugars are located. Over the years many pectin structural elements have been described and all pectins are believed to essentially contain the same repeating elements, although the amount and chemical fine structure of these elements varies [31-33]. A schematic representation of the composition of these structural elements is given in Fig. 1, which will be further discussed below.
Fig. 1 Schematic representation of pectin structural elements [142]

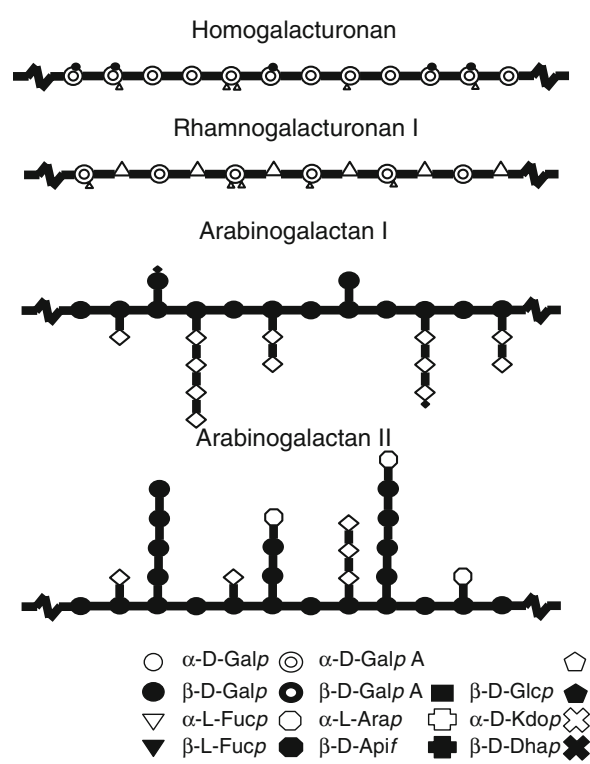

Homogalacturonan

Rhamnogalacturonan I

Arabinogalactan

Arabinogalactan II

$\nabla \alpha$-L-Fucp $\bigcirc \alpha$-L-Arap

$\nabla$-L-Fucp $\beta$-D-Apif

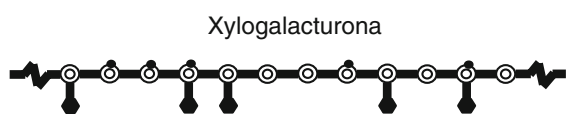

Rhamnogalacturonan II
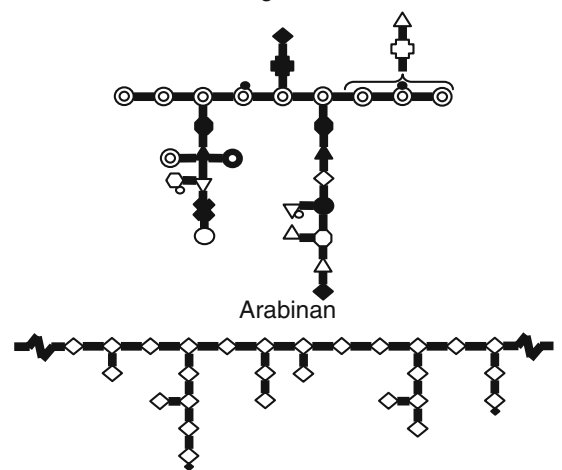

$\alpha$-L-Acef $A \diamond \alpha$-L-Araf $\triangle \alpha$-L-Rhap

$\beta$-D-Man $>\beta$-L-Araf $\Delta \beta$-L-Rhap

$\alpha$-D-Glcp A o O-Methyl $\Delta$ O-Acetyl

$\beta$-D-GIcp A - Methanol - O-Ferulic acid 


\section{Homogalacturonan}

Homogalacturonan (HG) is the major type of pectin in cell walls, accounting for approximately $60 \%$ of the total pectin amount [34, 35]. The HG polymer consists of a backbone of $\alpha$-1,4-linked GalA residues [7]. The minimum estimated length of this backbone is, for citrus, sugar beet, and apple pectin 72-100 GalA residues [36]. GalA moieties within this backbone may be methyl esterified at C-6 [37, 38] and/ or O-acetylated at O-2 and/or O-3 [39, 40]. The methylesterification in particular has gained a lot of attention in pectin research, because it strongly determines the physical properties of pectin. For instance, blocks of more than 10 non-esterified GalA residues yield pectin molecules that are sensitive to $\mathrm{Ca}^{2+}$ cross-linking [41]. However, not only the amount of methyl-esterification is important, but also the distribution of these esters is. The suggestion made by Rees and Wight [42] that HG elements could be interspersed with single L-rhamnose residues, resulting in a kink of the molecule, was convincingly argued against by Zhan et al. [43]. These authors could not isolate this internal rhamnose (Rha) from an endo-polygalacturase digest of citrus pectin, indicating a scarcity or complete lack of interspersing single rhamnose residues. Furthermore, based on molecular modeling, the presence of a kink in the molecule caused by interspersing Rha is further undermined [44].

\section{Xylogalacturonan}

Homogalacturonan substituted with $\beta$-D-Xylp-(1 $\rightarrow 3)$ single unit side chains is called xylogalacturonan (XGA) [42-44]. The degree of xylosidation can vary between $25 \%$ (watermelon) and 75\% (apple) [43-45]. Part of the GalA residues in XGA is methyl-esterified and the methyl esters are found to be equally distributed among the substituted and unsubstituted GalA residues [44, 45]. Although XGA has been mainly identified in reproductive tissues such as fruits and seeds [42, 44], Zandleven et al. [46] recently demonstrated the presence of this element in various tissues of Arabidopsis thaliana.

\section{Rhamnogalacturonan I}

The rhamnogalacturonan I (RGI) backbone is composed of $[\rightarrow 2)-\alpha$-L-Rhap- $(1 \rightarrow 4)-\alpha$ D-GalpA- $(1 \rightarrow]$ repeats $[42,47]$. Sycamore cells that are cultured in suspension can have as many as 300 repeats of this disaccharide [42, 47]. In contrast, in sugar beet pectin oligosaccharides with a maximum length of only 20 residues of alternating Rha and GalA units were isolated. However, it is unclear whether the acid hydrolysis extraction might have caused backbone breakdown, thus underestimating the RGI backbone length [48].
The rhamnosyl residues of RGI can be substituted at O-4 with neutral sugars side chains [49, 50, 47]. These side chains are mainly composed of galactosyl and/or arabinosyl residues. Both single unit $[\beta$-D-Galp- $(1 \rightarrow 4)]$ as well as polymeric substitutions, such as arabinogalactan I (AGI) and arabinan (50 glycosyl residues or more) have been identified [50, 51] in the side chains. The proportion of branched Rha residues varies from $\sim 20$ to $\sim 80 \%$ depending on the source of the polysaccharide [42].

The GalA residues of RGI are presumably not methyl esterified, because RGI is not degraded under $\beta$-eliminative circumstances [52]. On the other hand, a flax RGI fraction has been reported to contain $40 \%$ methyl esters [53]. The GalA residues in the RGI backbone may be highly Oacetylated on position $\mathrm{O} 2$ and/or O-3 of the GalA residues [54-57].

Rhamnogalacturonan hydrolase digestion of apple modified hairy regions (MHR) yielded specific populations, consisting out of $[\rightarrow 2)-\alpha$-L-Rhap- $(1 \rightarrow 4)-\alpha$-DGalpA- $(1 \rightarrow]$ repeats, with alternatively 0,1 , or 2 galactose substitutions to the rhamnose moieties. The ratio between these alternative substituted oligosaccharides suggests that hairy regions are composed, in part, of different repeating units [49]. Structural characterization of oligosaccharides released from sugar beet by dilute acid treatment showed single-unit $\beta$-D-GlcpA- $(1 \rightarrow 3)$ side chains attached to one of the GalA residues [58].

\section{Rhamnogalacturonan II}

Rhamnogalacturonan II (RGII) is a highly conserved structure in the plant kingdom and can be released by endopolygalacturonase action. The structure is characterized as a distinct region within $\mathrm{HG}$, containing clusters of four different side chains with very peculiar sugar residues, such as apiose, aceric acid, 3deoxy-lyxo-2-heptulosaric acid (DHA), and 3-deoxy-manno-2-octulosonic acid (KDO). These side chains are attached to a $\mathrm{HG}$ fragment of approximately nine GalA residues, of which some are methyl-esterified [3, 59, 60]. The structure of RGII seems to be highly conserved in the plant kingdom. RGII can complex together with Boron, forming a borate-diol ester, which can crosslink two HG molecules [60, 61]. Only the apiofuranosyl residues of the 2-O-methyl-D-xylose-containing side chains in each of the subunits of the dimer participate in the cross-linking [61].

\section{Arabinan}

Arabinan consist of a 1,5-linked $\alpha$-L-Araf backbone, which usually is substituted with $\alpha$-L-Araf-(1 $\rightarrow 2)$-, $\alpha$-L-Araf-(1 
$\rightarrow 3)$-, and/or $\alpha$-L-Araf-(1 $\rightarrow 3)-\alpha$-L-Araf-(1 $\rightarrow 3)$ - side chains $[1,3,54,56,62]$.

\section{Arabinogalactan I}

Arabinogalactan I (AGI) is composed out of a 1,4 linked $\beta$ D-Galp backbone with $\alpha$-L-Araf residues attached to O-3 of the galactosyl residues $[1,3,54]$. O- 6 substitution of the galactan backbone with $\beta$ galactose is also found [63]. The AGI backbone can be terminated with an $\alpha$-L-Arap- $(1 \rightarrow$ $4)$ at the non-reducing end [64]. Internal $-(1 \rightarrow 5)-\alpha-\mathrm{L}$-Araf linked arabinofuranose [64] and $(1 \rightarrow 3)-\beta$-D-Galp linked galactopyranose [65] residues have as well been identified.

\section{Arabinogalactan II}

Arabinogalactan II (AGII) is composed of a 1,3 linked $\beta$-DGalp backbone, containing short side chains of $\alpha$-L-Araf-( 1 $\rightarrow 6)$-[ $\beta$-D-Galp- $(1 \rightarrow 6)] \mathrm{n}(n=1,2$, or 3$)[1,3,54]$. The galactosyl residues of the side chains can be substituted with $\alpha$-L-Araf- $(1 \rightarrow 3)$ residues.

Arabinogalactan II is mainly associated with proteins (3$8 \%$ ), so called arabinogalactan proteins (AGPs). The protein part is rich in proline/hydroxyproline, alaline, serine, and threonine [66]. The major part of AGPs (>90\%) consists of polysaccharides. Pectin and AGII often co-extract and are subsequently difficult to separate from each other [67]. It has even been demonstrated that a small fraction of carrot tap root cell wall AGPs is linked to pectin [68].

\section{Enzymes used in structure elucidation of pectins}

Polysaccharide degrading enzymes are suitable tools to study the structure of pectin [33]. The main reason is the specificity of these enzymes in comparison to chemical methods, which are less-specific. Pectic enzymes are classified according to the mode of attack on their specific structural element of the pectin molecule [69]. Many detailed reviews have been dedicated to pectin degrading enzymes [62, 69-72] and therefore only the enzymes involved in the examination of polymeric pectin fragments described in this thesis (represented in Fig. 2) are briefly discussed in this chapter.

\section{Endo-polygalacturonase (EndoPG; EC 3.2.1.15)}

Endo-polygalacturonases (EndoPG's) cleave the $\alpha-1,4-\mathrm{D}$ galacturonan linkages in HG segments. EndoPG's generally prefer non-esterified substrate and show decreasing activity with increasing degree of methyl-esterification
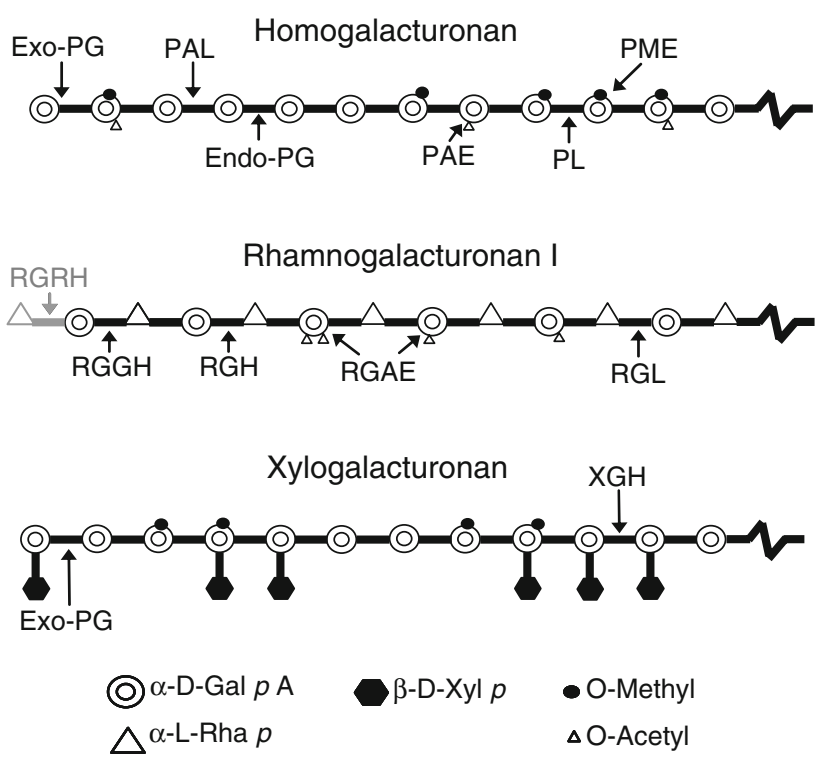

Fig. 2 Mode of action of pectinases involved in the degradation of homogalacturonan, rhamnogalacturonan I and xylogalacturonan (see text for abbreviations). Terminal end of rhamnogalacturonan $\mathrm{I}$ is represented in gray to stress that indicated exo-activity only exists with a single sugar moiety. Figure has been adapted from Hilz et al. [142]

[73]. The enzyme randomly attacks its substrate and produces a number of GalA oligosaccharides [74].

\section{Exopolygalacturonase (ExoPG; EC 3.2.1.67 and EC 3.2.1.82)}

ExoPG attacks the substrate from the non-reducing end and is able to remove terminally $(1 \rightarrow)$-linked GalA residues from HG chains. The enzyme requires a non-esterified GalpA unit at subsites $-2,-1$ and +1 [75] and is tolerant for xylose substitution (able to remove a GalA-Xyl dimer), hence XGA is also an ExoPG substrate [69, 70].

\section{Rhamnogalacturonan hydrolase (RGH; EC 3.2.1.-)}

Rhamnogalacturonan hydrolase hydrolyses the $\alpha$-D-1,4GalpA- $\alpha$-L-1,2-Rhap linkage in the RGI backbone, leaving Rhap at the non-reducing side [76]. Within the products formed, the Rha residues can be substituted with single galactose units [49].

The enzyme is intolerant for acetyl-esterification of the RGI backbone [70, 77].

\section{Rhamnogalacturonan lyase (RGL; EC 4.2.2.-)}

Degradation by RGL occurs through eliminative cleavage of the RGI $\alpha$-L-1,2-Rhap- $\alpha$ D-1,4-GalpA backbone leaving 
a 4-deoxy- $\beta$-L-threo-hex-4-enepyranosyluronic acid (unsaturated GalA) group at the non-reducing end [78-80]. Removal of arabinan side chains from saponified hairy regions of pectin resulted in an increased catalytic efficiency of Aspergillus aculeatus RGL, whereas the removal of galactan side chains decreases the enzyme efficiency [80]. The RGL activity increased after removal of acetyl groups [80].

\section{Rhamnogalacturonan rhamnohydrolase (RGRH)}

Rhamnogalacturonan rhamnohydrolase is an exo-acting pectinase, which possesses a specificity to release terminal rhamnosyl residues $(1 \rightarrow 4)$-linked to $\alpha$-galacturonosyl residues [81]. The enzyme is intolerant for (galactose) substitutions and has not yet been assigned to a glycosyl hydrolase family since no sequence information is available.

\section{Rhamnogalacturonan galacturono hydrolase (RGGH)}

Rhamnogalacturonan galacturono hydrolase is able to release a GalA moiety connected to a rhamnose residue from the non-reducing side of RGI chains but is unable to liberate GalA from HG [82]. Similar to RGRH no sequence information for RGGH is available.

\section{Endo xylogalacturonan hydrolase (XGH; EC 3.2.1.-)}

Xylogalacturonan hydrolase hydrolyses the $\alpha-1,4-D$ linkages of xylose substituted galacturonan moieties in XGA [83]. XGH has a requirement for xylosyl side chains and is therefore believed to cleave between two xylosidated GalpA residues [83]. Removal of ester linkages of galacturonan by saponification increases the enzyme activity [84].

\section{Cross links}

Although individual structural elements have been studied and their structures have been characterized, the knowledge on the interconnections between different structural elements with each other and with other polysaccharides is limited. Figure 3 represents a number of covalent and noncovalent linkages, which have been observed in pectin
A

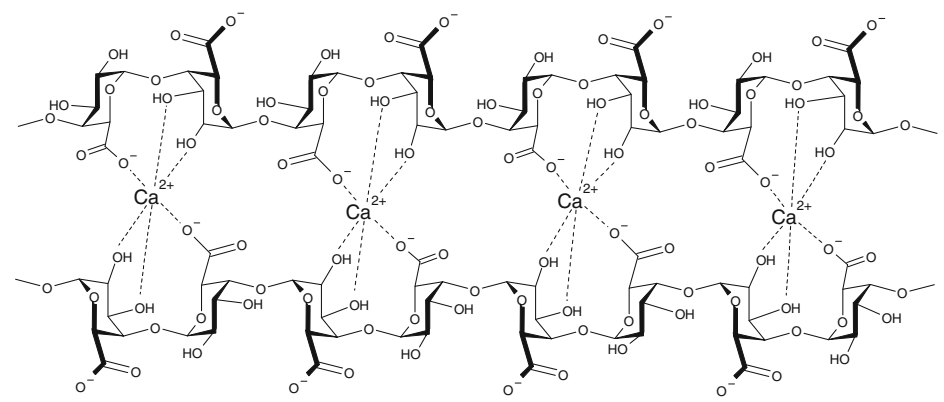

C

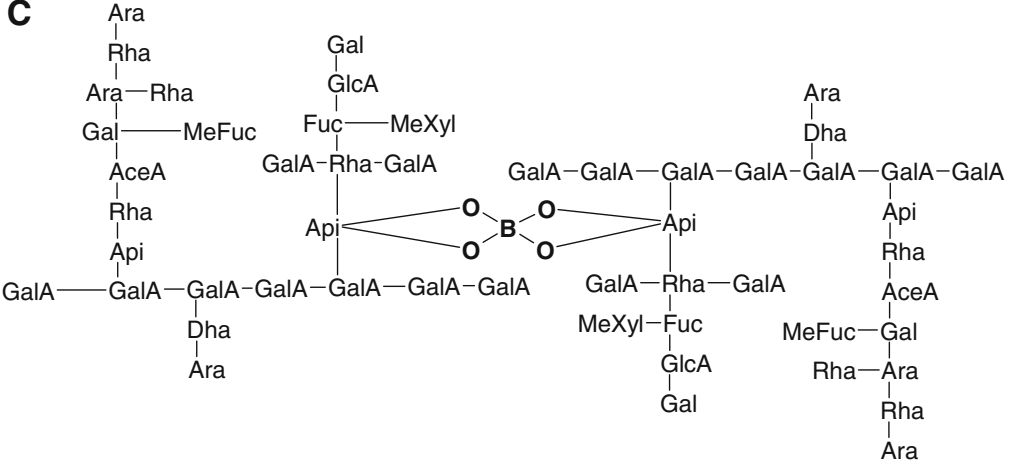

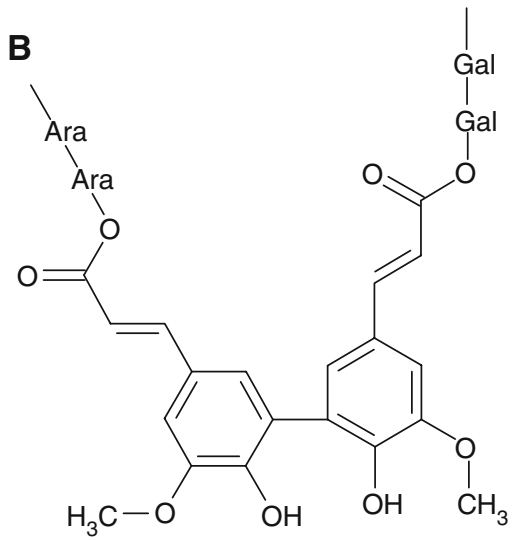

D

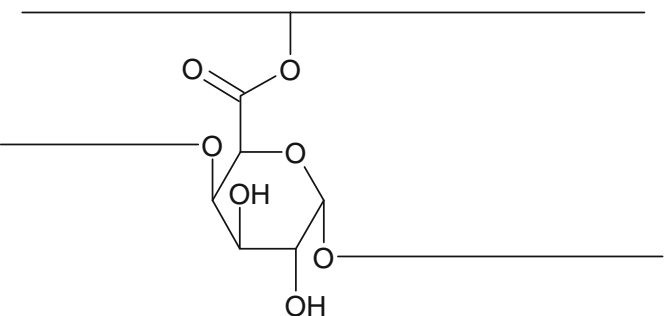

Fig. 3 Pectin cross links as described in literature. a Calcium-pectincrosslink as egg box model [86], b 5-5-diferulic esterified with neutral sugar side chains of pectin [144], c Rhamnogalacturonan II diester
[61], d uronyl ester of pectin with a hydroxyl group of another polysaccharide chain [95]. Figure adapted from Hilz [142] 
polymers, and are possibly involved in intra- or intermolecular linkages.

\section{Calcium-pectin complexes}

Low methyl-esterified pectins are thought to gel according to the egg box model [85], first suggested for alginates [86]. Sections of two pectic chains, which must be free of ester groups, are held together by a number of calcium ions. It is reported that blocks of 7-20 free GalA residues are required for association with calcium [87-89].

\section{Ferulic acid esters}

Pectins originating from spinach and sugar beet contain ferulic acid residues in the arabinan side chains. In sugar beet, $45-50 \%$ of ferulic acid can be attached to the O-6 position of galactose residues in $(1 \rightarrow 4)$-linked galactans [90-93]. Ferulic acid dihydrodimers account for approximately $22 \%$ of the total ferulates in sugar beet pectin [94].

\section{Rhamnogalacturonan II dimer formation}

The demonstration that RGII exists in primary walls as a dimer that is covalently crosslinked by a borate diester [61] was a major advance in the understanding of the structure and function of this pectic polysaccharide. RGII is covalently linked to $\mathrm{HG}$ and as a consequence dimer formation results in the cross-linking of two HG chains, which could lead to the formation of a three-dimensional pectic network in muro [60]. This network contributes to the mechanical properties of the primary wall and is required for normal plant growth and development. Changes in wall properties resulting from decreased borate cross-linking of pectin lead to many of the symptoms associated with boron deficiency in plants $[2,60,61]$.

\section{Uronyl esters}

Lamport [95] suggested that HG could be linked to relatively non-polar putative alcohols by uronyl esters. In pectin originating from cultured spinach cells up to approximately $5 \%$ of the GalA residues could be crosslinked in this way [96]. These observations have been revisited, with the additional hypothesis that (particular) pectin methylesterase(s) (PME) could catalyze a transesterification reaction [97]. The energy imparted in the methyl ester bond is used in the wall by PME to synthesize cross-links between HG chains; the methanol is released and the carboxylgroup of the galacturonosyl moiety is attached to a $-\mathrm{OH}$ group of a galacturonosyl moiety of another HG chain. As HG is mainly deposited in the cell wall in a methylesterified form, it is evident that these molecules hold an enormous potential for cross-linking. Interestingly, within the Arabidopsis genome, about 60 PME genes have been found that await further characterization [98]. It is possible that PMEs specialized in catalyzing the formation of uronyl esters can be found among these. More work is needed to further substantiate the abundance, formation, and role of this cross-link.

\section{Pectin models}

In 1934 pectin obtained from citrus fruits was recognized/ visualized as a primarily linear polygalacturonic acid [99]. Although this idealized view has been used in handbooks till the nineties of the last century, pectin structural data collected over the last decades have drastically changed this view on pectin's structure. It has become clear that pectin is a very complex macromolecule and that it is a big challenge to accommodate all available information in a model structure. Some of the most cited hypothetical models are summarized below.

\section{Rhamnogalacturonan model}

The backbone of pectin isolated from sycamore cells was defined as RG, consisting out of chains of $\alpha$-1,4-linked galacturonosyl residues interspersed with 2-linked Rha residues. The rhamnosyl residues were considered not to be randomly distributed in the chain, but probably to occur in sequences of the rhamnosyl - $(1 \rightarrow 4)$-galacturonosyl- $(1 \rightarrow$ $2)$ - disaccharide. This sequence appeared to alternate with HG sequences, containing approximately eight residues of 4-linked GalA. About half of the rhamnosyl residues were found to be branched, having a substituent attached to O-4. This was considered to be the attachment site of the 4linked galactan [100]. A schematic representation of this model is given in Fig. 4.

\section{Smooth and hairy regions model}

De Vries et al. [31] demonstrated that the distribution of the neutral sugars in apple pectin is discontinues. By analysis of enzymatic digests it was found that all neutral sugars were located on $5 \%$ of the galacturonosyl residues, constituting the so-called hairy regions. The degradable unsubstituted part was defined as the smooth region (HG). The observed neutral sugar distribution curves, obtained by anion-exchange and size-exclusion chromatography, 


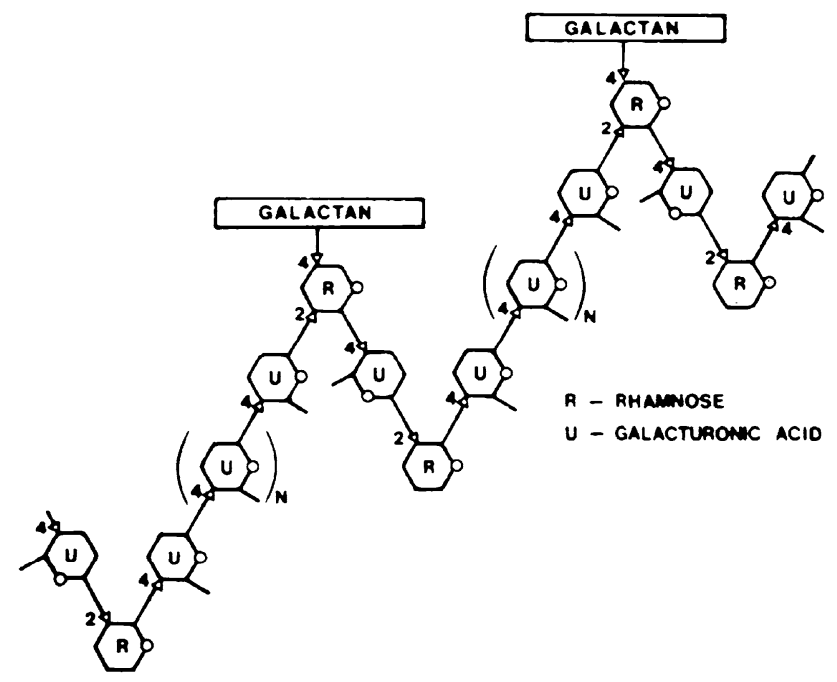

Fig. 4 A proposed structure for the rhamnogalacturonan. The sugar residues in the figure are designated as $R=$ rhamnose and $U=$ galacturonic acid. $N=$ an undetermined number, probably between 4 and 10. Reprinted from Talmadge et al. [100]. Copyright American Society of Plant Biologists (http://www.plantphysiol.org)

indicated a specific ratio of smooth versus hairy regions within the different eluted populations. Since hairy regions contain only $5 \%$ of the GalA residues, the molecular weight of pectin must be very high. In fractions of extracts obtained with various extractants from ripe and unripe and fractionation by anion-exchange chromatography three main types of pectin molecules were identified, having one, two, or three hairy regions, respectively. These types were identified by grouping subfractions with equal amounts of anhydrogalacturonic acid according to the ratio of moles neutral sugars per mole anhydrogalacturonic acid present.

A model was constructed (Fig. 5), placing the neutral sugar side chains in blocks at regular intervals and close to the chain ends, hereby providing an explanation for the inverse relationship between the neutral sugar content and the apparent molecular weight of some pectins $[30,31]$.

\section{Enzymatically updated smooth and hairy regions model}

Discovery of the enzyme RGH [76] enabled fragmentation of hairy regions and a better identification of the building blocks. Based on degradation products of RGH, hairy regions are considered to consist of XGA segments (subunit I); rhamnogalacturonan stubs rich in arabinan side chains (subunit II), and of RGH oligosaccharides as released from the rhamnogalacturonan region (subunit III). The pectin model was refined (Fig. 6), using the relative amounts of the different subunits present in cell wall digests of various plant sources. Based on these findings, pectin is believed to be a block polymer composed of structural elements accommodated in hairy regions, interspersed by smooth (HG) regions containing 70-100 GalA residues $[33,36]$. The position of RGII is not addressed in this model, but this structural element is believed to be an integral part of some HG segments, which can crosslink two HG molecules [42, 60, 61].

\section{RGI backbone model}

Vincken et al. [67] listed a number of observations, which challenged the smooth and hairy regions model:

- No evidence exists for the presence of single interspacing rhamnosyl moieties within the HG smooth regions [101]. These linkages were incorporated in the smooth and hairy regions model to explain the observed length-periodicity [36, 102] of HGs after treatment with dilute acid.

- The release of substantial XGA type oligosaccharides by ExoPG [70] combined with a modest decrease in Mw by EndoXGH, makes an internal position of XGA unlikely. The most plausible explanation is that XGA is a side chain [67].

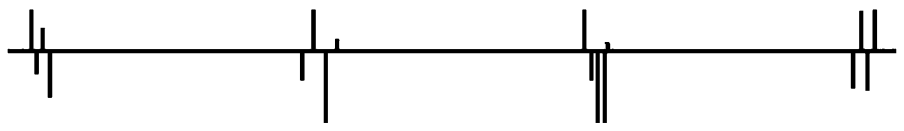

type A type E

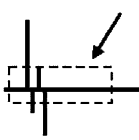

type B

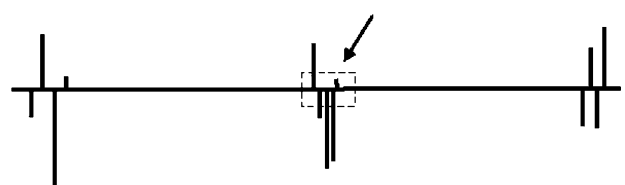

type C

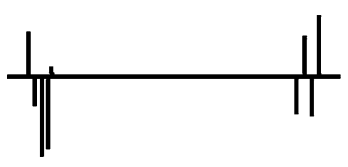

type D
Fig. 5 Pectin model based upon the sugar composition and molecular weights of the different pectin extracts B, C, and D. Type A and Type $\mathrm{E}$ are considered to be degraded pectins. Horizontal lines: rhamnogalacturonan backbone of the pectin molecule. Branched areas: blocks of neutral sugar side chains (number and length are arbitrary). Reprinted from de Vries et al. [30], with permission from Elsevier 


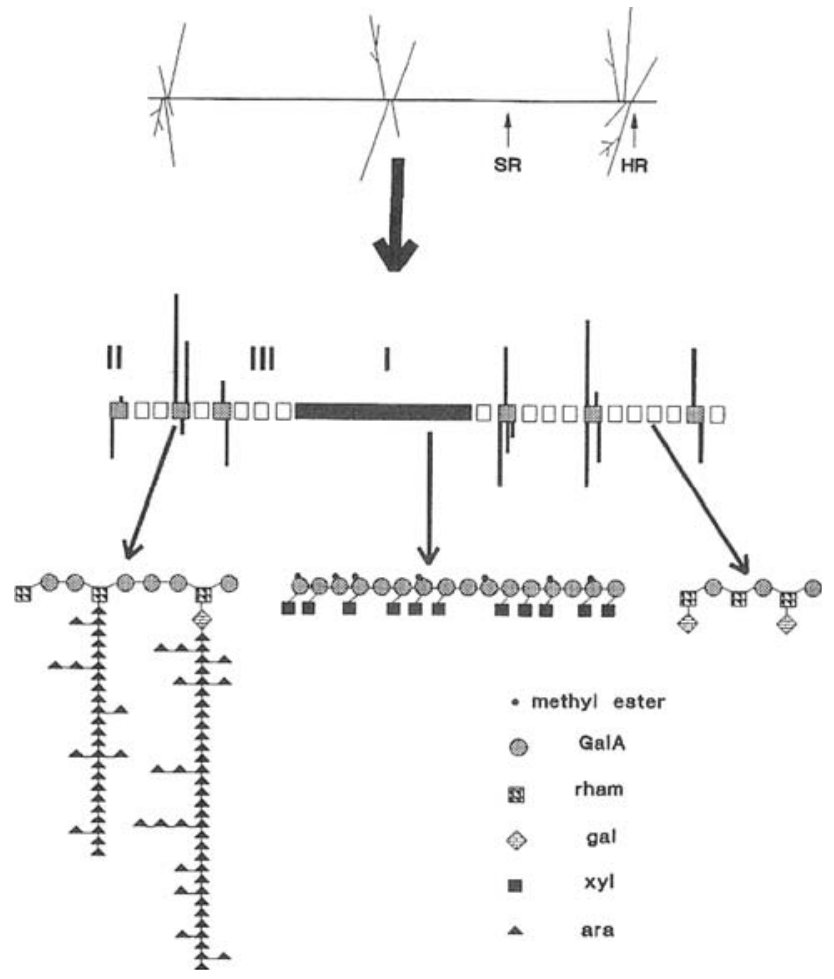

Fig. 6 Hypothetical structure of apple pectin and of the prevailing population of MHR isolated here from. SR, smooth regions; HR, hairy regions. Subunit I, xylogalacturonan; subunit II, stubs of the backbone rich in arabinan side chains; subunit III, rhamnogalacturonan hydrolase oligosaccharides. Reprinted from Schols and Voragen [33], with permission from Elsevier

- A detailed structural analysis of the rhamnogalacturonan segment, substituted with arabinan and arabinogalactan side chains, revealed that after removal of the arabinan side chains, EndoPG could release oligogalacturonides from these rhamnogalacturonan segments. The released fragments are not likely an integral part of the backbone, since only GalA oligosaccharides were detected. Together with the GalA:Rha ratio, which contains an excess of GalA, this indicates that part of the GalA residues are present in side chains of RGI or as remaining stubs on chain ends [47, 67].

- It is likely that many different synthetases are involved in the biosynthesis of the HG and RGI backbones, and that there is no single enzyme complex known to synthesize the "pectin backbone" [67].

A new model (Fig. 7) was thereafter introduced to incorporate the listed findings presented above [67]. Homogalacturonan was located as a side chain of RGI, where the HG side chains can either be attached to the rhamnosyl residues of RGI, or to GalA residues of RGI [67]. It does not seem unreasonable that $\mathrm{HG}$ is a side chain of RGI, because HG and XGA have the same backbone structure [67].

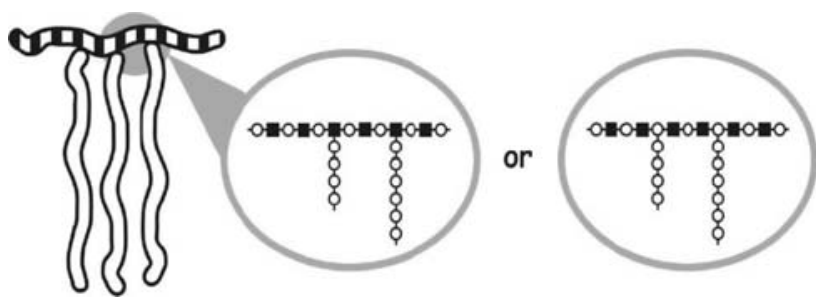

Fig. 7 Schematic illustration of the pectin model as described by Vincken et al. [67]. RGI is decorated with HG side chains, where it is unknown where these side chains are attached. Reprinted with permission from Springer Science and Business Media

\section{Neutral sugar side chains}

Literature suggests that RGI can differ in its "hairstyle" [103-106]. In both the linear and branched model arabinan and arabinogalactan are depicted as side chains attached to a rhamnose moiety within RGI. Although, some older reports describe covalent linkage between arabinose to GalA [107]. The arrangement of the various structural elements remains speculative. RGH is a typical endo-acting enzyme, which is characterized by the generation of large products in the early stages of the reaction $[69,108]$. The release of varying small oligosaccharides out of apple MHR by RGH indicates that regions of scarcely substituted alternating rhamnose and GalA sequences are not extremely long, and probably interrupted with other structures resistant to RGH [33]. The enzymatic breakdown might be hindered by several side chains, which are highly flexible and sufficiently long to be able to wrap around the RGI backbone [106]. Therefore, the distribution of the neutral sugars over the RGI backbone could influence the degradability of this structural element, further complicating the elucidation of pectin structure.

\section{Pectins from different sources}

Hairy regions isolated from plant material of other origin like leek, onion, carrot, pear, and potato principally consists of the same building blocks, although the arrangement of these blocks as well as the arabinose and xylose content may vary [57]. In all examined sources, RGH treatment resulted in MHR degradation, but the Mw distribution behavior of remaining fragments varied significantly. Degradation by RGH of MHR fractions from different sources resulted in the same series of RGH oligosaccharides [108]. For different extracts (e.g., hot buffer soluble solids versus dilute alkali soluble solids) from one specific source, it is suggested that the released fragments are originating from the extremities of the molecules, whereas in another extract, they are thought to be distributed more randomly over the pectin molecule [108]. Therefore, the ratio between the subunits I, II, and III (Fig. 5) may vary. Especially the presence of XGA 
Table 1 Occurrence and proportions of the various structural elements in natural products

\begin{tabular}{|c|c|c|c|c|c|c|}
\hline & Black currant $^{\mathrm{a}}$ & Bilberry $^{\mathrm{a}}$ & Grape $^{\mathrm{b}}$ & Soybean $^{\mathrm{c}}$ & Sugar beet ${ }^{\mathrm{c}}$ & Apple $^{\mathrm{c}}$ \\
\hline Total polysaccharides ( $\%$ of dry matter) & 19 & 12 & 11 & 16 & 67 & 20 \\
\hline Pectic substances (\% of total PS) & 61 & 33 & 56 & 59 & 40 & 42 \\
\hline \multicolumn{7}{|l|}{ Structural element ( $\%$ of pectic substances) } \\
\hline Homogalacturonan & 68 & 65 & 65 & 0 & 29 & 36 \\
\hline Xylogalacturonan & 0 & 0 & n.a. & 21 & $<1$ & 4 \\
\hline Rhamnogalacturonan I & 5 & 6 & 10 & 15 & 4 & 1 \\
\hline Neutral side chains & 24 & 27 & 23 & 60 & 48 & 47 \\
\hline Rhamnogalacturonan II & 3 & 2 & $2 \mathrm{c}$ & 4 & 4 & 10 \\
\hline
\end{tabular}

n.a. $=$ not analyzed

${ }^{\text {a }}$ From Hilz [142]

b Recalculated from Nunanet al. [143]

${ }^{c}$ From Voragen et al. [110]

subunit seems to depend on the MHR origin [57]. Although the ratio between the different pools varied significantly, their size distribution was identical as well as the presence of different structural elements [31-33, 108], therefore an apple based pectin model might also be valid for pectin isolated from other plant sources. In Table 1 the occurrence and proportions of the various pectin structural elements from different sources is described, demonstrating that the same structural elements occur in various quantities in different plant sources. Homogalacturonan and XGA structural elements seem to be confined to specific species $[109,110]$.

\section{Uncharted areas}

In apple, pear, carrot, leek, onion, and potato MHR, typical enzyme resistant polymers exist $[44,57]$. These polymers have a Rha:GalA ratio of roughly 1:2 and a mass of around $5.4 \mathrm{kDa}$ [56]. Even after de-esterification these structures cannot be degraded by HG nor by RGI degrading enzymes, hampering complete structural elucidation of pectin. The backbone structure of these enzyme resistant polymers may even deviate from a strictly alternating sequence, resulting in short chains of, e.g., GalA (or Rha), which would confirm previous findings, such as a dimer of rhamnose-(1,2)rhamnose [111], GalpA-(1,4)-GalpA-(1,2)-Rha [112], $\operatorname{GalA(1,2)-Rhap-(1,2)-Rhap~[112],~GalA(1,4)-GlcA~[58]~}$ The presence of these polymer populations, which cannot be analyzed in detail, demonstrate the requirement for novel degradation and/or analysis techniques.

\section{Release, fractionation, and identification of connection points}

Why has the linkage between RGI and HG not been demonstrated until now? The scarcity of the HG-RGI linkage, in combination with the difficulty to find selective methods to enrich a particular fraction in the cross-link, are beyond doubt important reasons [113]. In order to determine indisputably how the different structural elements are linked to each other, linkage points have to be isolated and their structures identified.

\section{Chemical degradation}

To be able to reveal its structure, pectin is commonly degraded in to smaller oligosaccharides, as the pectin molecule is too large and heterogeneous to analyze as a whole [114]. Pectins can be rather selectively degraded through partial acid hydrolysis, where advantage is taken from the different hydrolysis rates of various glycosidic bonds $[115,116] . \beta$-Elimination is an alternative fractionation method for pectin oligosaccharides. This reaction occurs at neutral or even weakly acidic conditions and is competing with the de-esterification reaction [117]. Cold alkali treatment promotes de-esterification rather than the competitive B-elimination reaction $[52,118]$. This procedure, also known as saponification, results in simplified chromatograms and spectra due to the removal of acetyl and methyl esters $[119,120]$.

\section{Enzymatic degradation}

Next to the chemical degradation methods, enzymes are used in structure research because of their specificity and selectivity [85]. Pure enzymes have been used to hydrolyze complex carbohydrates, in order to reveal structural characteristics [76, 121]. The complexity of pectin hampers enzymatic degradation. As a consequence, a lot of substitutions and structural organisations require treatment with 
several enzymes simultaneously or in a particular sequence for degradation [122, 123]. Several pectin degrading enzymes have been demonstrated to act synergistically [124]. When pectin structures are not degradable by the available enzymes, a combination of chemical and enzymatic approaches can be applied. For instance, in the structural characterization of enzyme resistant highly branched RGI structures, partial side chain removal by chemical treatments enables subsequent enzymatic breakdown [78, 125-127]. Furthermore, the enzyme activity of EndoPG [77, 122], and XGH [83] improved after removal of acetyl groups and/or methyl esters.

\section{Analytical approaches}

Before pectin can be characterized on a structural level, it has to be extracted out of the cell wall matrix, usually by sequential extraction steps with different buffers [128, 129]. The molecular weight can be estimated with sizeexclusion chromatography. The sugar composition [130, 131], the sugar linkage composition [132], and the degree of methylation and acetylation [133] of the extracted pectin can be determined among several other possible analyses. These analyses, which are conducted on the whole molecule, are, however, not sufficient to give insight in the pectin structure. Therefore, pectin is often degraded by chemical or enzymatic approaches. The effect of this degradation is twofold; "pure" structural elements can be obtained after fractionation of the degradation products, and the resulting fragments are in the analytical range of a broad set of analytical techniques [134], such as high performance anion-exchange chromatography (HPAEC), capillary electrophoresis (CE) and mass spectrometry (MS). Using HPAEC, sugar oligosaccharides are separated based on their charge differences. The separation is performed at $\mathrm{pH} 12$ to ensure that even neutral sugars are charged. The negatively charged sugars bind to the column material and elute through competitive binding with an increasing salt gradient [135]. As an alternative, pectin oligosaccharides can be analyzed at $\mathrm{pH} 5$ to retain information about methyl esters distribution over the backbone [136]. After elution, sugars are often detected by a pulsed ampherometric detector [135]. An alternative separation for pectin oligosaccharides can be obtained by $\mathrm{CE}$, using the negative charge of pectin oligosaccharides at high $\mathrm{pH}$, or introduced charges by coupling pectin oligosaccharides to a charged label $[137,138]$. In both HPAEC and CE techniques, the eluting oligosaccharides are annotated based on their elution times relative to standards [135, 137]. However, for many complex oligosaccharides, standards are not available [135]. To circumvent this shortcoming, the HPLC eluent can be fractionated and analyzed off line by mass spectrometric techniques [139]. The combination of low sample quantity together with intrinsic difficulties for fractionation, make CE less suitable for sequential MS analysis. Therefore, HPAEC is the most frequently used technique to identify sugar oligosaccharides, sometimes in combination with off-line MS [139, 135]. Matrix assisted laser desorption/ionisation MS is often used for offline MS analysis, due to its tolerance to residual salts, the relative simple sample preparation, and high speed of analysis [136]. Using this technique, masses of oligosaccharides and their MS-fragmentation products can be determined [140]. Iontrap MS is used as an alternative to gain more detailed structural information of a specific compound, through multiple MS analysis stages [141].

It is clear that the structure of pectin cannot be drawn based upon results from one single analytical method, but a combination of different analytical methods combined with several sample preparation procedures is needed.

\section{Concluding remarks}

Considerable progress has been made in the elucidation of the fine chemical structure of pectin due to the availability of novel pectin modifying enzymes and their use as analytical tools and the development of advanced chromatographic, spectroscopic, and immune-labeling techniques. These techniques have enabled us to identify the structural elements making up the pectin molecule and their localization in plant tissues and in the plant cell wall, the structural variation in pectin's depending from different developmental stages or from different sources.

Open Access This article is distributed under the terms of the Creative Commons Attribution Noncommercial License which permits any noncommercial use, distribution, and reproduction in any medium, provided the original author(s) and source are credited.

\section{References}

1. Mohnen D (1999) In: Barton D, Nakanishi K, Meth-Cohn O (eds) Comprehensive natural products chemistry, Elsevier, Dordrecht, The Netherlands, pp 497-527

2. O'Neill MA, Ishii T, Albersheim P, Darvill AG (2004) Annu Rev Plant Biol 55(1):109. doi:10.1146/annurev.arplant.55. 031903.141750

3. Ridley BL, O'Neill MA, Mohnen D (2001) Phytochemistry 57:929. doi:10.1016/S0031-9422(01)00113-3

4. Crombie HJ, Scott C, Reid JSG (2003) In: Voragen AGJ, Schols HA, Visser RGF (eds) Advances in pectin and pectinase research. Kluwer Academic Publishers, Dordrecht, pp 35-45

5. Fry SC (1988) The growing plant cell wall: chemical and metabolic analysis. Longman Scientific \& Technical, Harlow, pp 103-185

6. Fischer RL, Bennett AB (1991) Annu Rev Plant Physiol Plant Mol Biol 42(1):675. doi:10.1146/annurev.pp.42.060191.003331 
7. McNeil M, Darvill AG, Fry SC, Albersheim P (1984) Annu Rev Biochem 53(1):625. doi:10.1146/annurev.bi.53.070184.003205

8. Hahn MG, Darvill AG, Albersheim P (1981) Plant Physiol 68(5):1161. doi:10.1104/pp.68.5.1161

9. Jin DF, West CA (1984) Plant Physiol 74(4):989. doi:10.1104/ pp.74.4.989

10. Nothnagel EA, McNeil M, Albersheim P, Dell A (1983) Plant Physiol 71(4):916. doi:10.1104/pp.71.4.916

11. Robertsen BB (1986) Physiol Mol Plant Pathol 28(1):137

12. Bishop PD, Pearce G, Bryant JE, Ryan CA (1984) J Biol Chem 259(21): 13172

13. Laurent MA, Boulenguer P (2003) Food Hydrocoll 17(4):445. doi:10.1016/S0268-005X(03)00028-6

14. Pilgrim GW, Walter RH, Oakenfull DG (1991) In: Walters RH (ed) The chemistry and technology of pectin. Academic Press Inc., San Diego, pp 23-50

15. Pilnik W, Voragen AGJ (1970) In: Hulme HC (ed) The biochemistry of fruits and their products, vol 1. Academic Press, London, pp 53-87

16. Bock W, Krause M (1978) Ernahrungsforschung 23(4):100

17. Cummings JHJH (1979) Br J Nutr 41(3):477. doi:10.1079/ BJN19790062

18. Becker BB, Kuhn UU, Hardewig Budny BB (2006) Arzneimittelforschung 56(6):387

19. Guggenbichler JP, De Bettignies-Dutz A, Meissner P, Schellmoser S, Jurenitsch J (1997) Pharm Pharmacol Lett 7(1):35

20. Kastner U, Glasl S, Follrich B, Guggenbichler JP, Jurenitsch J (2002) Wien Med Wochenschr 152(15-16):379. doi: 10.1046/j.1563-258X.2002.02057.X

21. Langhout DJ, Schutte JB, Van Leeuwen P, Wiebenga J, Tamminga S (1999) Br Poult Sci 40(3):340. doi:10.1080/00071 669987421

22. Lim BO, Yamada K, Nonaka M, Kuramoto Y, Hung P, Sugano M (1997) J Nutr 127(5):663

23. Kay RM, Judd PA, Truswell AS (1978) J Clin Nutr 31(4):562

24. Mokady SS (1973) Nutr Metab 15(4-5):290. doi:10.1159/ 000175452

25. Trumbo P, Schlicker S, Yates AA, Poos M (2002) J Am Diet Assoc 102(11):1621. doi:10.1016/S0002-8223(02)90346-9

26. Jenkins DA, Leeds A, Wolever TS, Goff D, George K, Alberti MM, Gassull M, Derek T, Hockaday R (1976) Lancet 308(7978):172. doi:10.1016/S0140-6736(76)92346-1

27. Williams DRR, James WPT, Evans IE (1980) Diabetologia 18(5):379

28. Yamada H, Kiyohara H, Matsumoto T (2003) In: Voragen AGJ, Schols HA, Visser RGF (eds) Advances in pectin and pectinase research. Kluwer Academic Publishers, Dordrecht, pp 481-490

29. Kertesz ZI (1951) The pectic substances. Interscience publishing, New York-London

30. De Vries JA (1983) Structural features of apple pectin substances. Doctoral Thesis. Wageningen University

31. De Vries JA, Voragen AGJ, Rombouts FM, Pilnik W (1981) Carbohydr Polym 1:117. doi:10.1016/0144-8617(81)90004-7

32. McNeill M, Darvill AG, Albersheim P (1979) The structural polymers of the primary cell walls of dicots. Springer-Verlag, Vienna

33. Schols HA, Voragen AGJ (1996) In: Visser J, Voragen AGJ (eds) Pectins and pectinases. Elsevier Science B.V., Amsterdam, pp 3-21

34. Mohnen D, Doong RL, Liljebjelke K, Fralish G, Chan J (2003) In: Visser J, Voragen AGJ (eds) Pectins and pectinases. Elsevier Science B.V., Amsterdam, pp 109-127

35. O'Neill M, Albersheim P, Darvill A (1990) In: Dey PM (ed) Methods in plant biochemistry. Academic Press, London, pp $415-441$
36. Thibault JF, Renard CMGC, Axelos MAV, Roger P, Crepeau MJ (1993) Carbohydr Res 238:271

37. Gee M, Reeve RM, McCready RM (1959) J Agric Food Chem 7(1):34. doi:10.1021/jf60095a005

38. Mort AJ, Qiu F, Maness NO (1993) Carbohydr Res 247:21. doi: 10.1016/0008-6215(93)84238-2

39. Ishii TT (1995) Mokuzai Gakkaishi 41(7):669

40. Rombouts FM, Thibault JF (1986) In: Fishman ML, Chen JJ (eds) ACS Symposium Series, American Chemical Society, Washington D.C., pp 49-60

41. Daas PJH, Boxma B, Hopman AMCP, Voragen AGJ, Schols HA (2001) Biopolymers 58:1. doi:10.1002/1097-0282(200101) 58:1<1::AID-BIP10>3.0.CO;2-I

42. Albersheim P, Darvill AG, O'Neill MA, Schols HA, Voragen AGJ (1996) In: Visser J, Voragen AGJ (eds) Pectins and pectinases. Elsevier Science B.V., Amsterdam, pp 47-56

43. Le Goff A, Renard CMGC, Bonnin E, Thibault JF (2001) Carbohydr Polym 45(4):325. doi:10.1016/S0144-8617(00)00271-X

44. Schols HA, Bakx EJ, Schipper D, Voragen AGJ (1995) Carbohydr Res 279:265. doi:10.1016/0008-6215(95)00287-1

45. Yu L, Mort AJ (1996) In: Visser J, Voragen AGJ (eds) Pectins and pectinases, Elsevier Science B.V., Amsterdam, pp 79-88

46. Zandleven J, Sorensen SO, Harholt J, Beldman G, Schols HA, Scheller HV, Voragen AGJ (2007) Phytochemistry 68(8):1219. doi:10.1016/j.phytochem.2007.01.016

47. McNeil M, Darvill A, Albersheim P (1980) Plant Physiol 66(6): 1128. doi: 10.1104/pp.66.6.1128

48. Renard CMGC, Crepeau MJ, Thibault JF (1995) Carbohydr Res 275(1):155. doi:10.1016/0008-6215(95)00140-O

49. Colquhoun IJ, de Ruiter GA, Schols HA, Voragen AGJ (1990) Carbohydr Res 206(1):131. doi:10.1016/0008-6215(90)84012-J

50. Lau J, Mc M, Neil M, Darvill AG, Albersheim P (1987) Carbohydr Res 168(2):245. doi:10.1016/0008-6215(87)80029-0

51. Lerouge P, O'Neill MA, Darvill AG, Albersheim P (1993) Carbohydr Res 243(2):359

52. Kravtchenko TP, Arnould I, Voragen AGJ, Pilnik W (1992) Carbohydr Polym 19(4):237. doi:10.1016/0144-8617(92) 90075-2

53. Rihouey C, Morvan C, Borissova I, Jauneau A, Demarty M, Jarvis M (1995) Carbohydr Polym 28(2):159. doi: 10.1016/0144-8617(95)00094-1

54. Carpita NC, Gibeaut DM (1993) Plant J 3(1):1. doi:10.1111/ j.1365-313X.1993.tb00007.x

55. Komalavilas P, Mort AJ (1989) Carbohydr Res 189:261. doi: 10.1016/0008-6215(89)84102-3

56. Schols HA, Posthumus MA, Voragen AGJ (1990) Carbohydr Res 206(1):117. doi:10.1016/0008-6215(90)84011-I

57. Schols HA, Voragen AGJ (1994) Carbohydr Res 256(1):83. doi: 10.1016/0008-6215(94)84229-9

58. Renard CMGC, Crépeau MJ, Thibault JF (1999) Eur J Biochem 266:566. doi:10.1046/j.1432-1327.1999.00896.x

59. O'Neill MA, Eberhard S, Albersheim P, Darvill AG (2001) Science 294:846

60. Ishii $\mathrm{T}$, Matsunaga $\mathrm{T}$ (2001) Phytochemistry 57:969. doi: 10.1016/S0031-9422(01)00047-4

61. Ishii T, Matsunaga T, Pellerin P, O'Neill MA, Darvill A, Albersheim P (1999) J Biol Chem 274(19):13098. doi: 10.1074/jbc.274.19.13098

62. Beldman G, Schols HA, Pitson SM, Searle-van Leeuwen MJF, Voragen AGJ (1997) In: Sturgeon RJ (ed) Advances in macromolecular carbohydrate research. JAI Press Inc., London, pp 164

63. van de Vis JW (1994) Characterization and mode of action of enzymes degrading galactan structures of arabinogalactans. Doctoral Thesis, Wageningen University 
64. Huisman MMH, Brull LP, Thomas Oates JE, Haverkamp J, Schols HA, Voragen AGJ (2001) Carbohydr Res 330(1):103. doi:10.1016/S0008-6215(00)00269-X

65. Hinz SWA, Verhoef R, Schols HA, Vincken JP, Voragen AGJ (2005) Carbohydr Res 340(13):2135

66. Gaspar Y, Johnson KL, McKenna JA, Bacic A, Schultz CJ (2001) Plant Mol Biol 47(1):161

67. Vincken JP, Schols HA, Oomen RJFJ, Beldman G, Visser RGF, Voragen AGJ (2003) In: Voragen AGJ, Schols HA, Visser RGF (eds) Advances in pectin and pectinase research. Kluwer Academic Publishers, Dordrecht, pp 47-60

68. Immerzeel P, Eppink MM, de Vries SC, Schols HA, Voragen AGJ (2006) Physiol Plant 128(1):18

69. Benen JAE, Vinken JP, Alebeek GWM (2002) In: Seymour GB, Knox JP (eds) Pectins and their manipulation. Blackwell Publishing, Oxford, pp 174-180

70. Beldman G, Mutter M, Searle-Van Leeuwen MJF, Van den Broek LAM, Schols HA, Voragen AGJ (1996) In: Visser J, Voragen AGJ (eds) Pectins and pectinases. Elsevier Science B.V., Amsterdam, pp 231-245

71. Fischer RL, Bennett AB (1991) Annu Rev Plant Physiol Plant Mol Biol 42:1-21

72. Prade R, Zhan D, Ayoubi P, Mort A (1999) Biotechnol Genet Eng Rev 16:361

73. Parenicovà L, Benen JA, Kester HC, Visser J (2000) Biochem J 345(3):637

74. Osteryoung KW, Toenjes K, Hall B, Winkler V, Bennett AB (1990) Plant Cell 2(12):1239

75. Kester HCM, Magaud D, Roy C, Anker D, Doutheau A, Shevchik V, Hugouvieux-Cotte-Pattat N, Benen JAE, Visser J (1999) J Biol Chem 274(52):37053

76. Schols HA, Gereads CCJM, Searle-van Leeuwen MF, Kormelink FJM, Voragen AGJ (1990) Carbohydr Res 206:105

77. Kauppinen S, Christgau S, Kofod LV, Halkier T, Dörreich K, Dalbøge H (1995) J Biol Chem 270(45):27172

78. Azadi P, O'Neill MA, Bergmann C, Darvill AG, Albersheim P (1995) Glycobiology 5(8):783

79. Mutter M, Colquhoun IJ, Schols HA, Beldman G, Voragen AGJ (1996) In: Visser J, Voragen AGJ (eds) Pectins and pectinases. Elsevier Science B.V., Amsterdam, pp 783-787

80. Mutter M, Colquhoun IJ, Beldman G, Schols HA, Bakx EJ, Voragen AGJ (1998) Plant Physiol 117(1):141

81. Mutter M, Beldman G, Schols HA, Voragen AGJ (1994) Plant Physiol 106:241

82. Mutter M, Beldman G, Pitson SM, Schols HA, Voragen AGJ (1998) Plant Physiol 117(1):153

83. van der Vlugt-Bergmans CJB, Meeuwsen PJA, Voragen AGJ, van Ooyen AJJ (2000) Appl Environ Microbiol 66(1):36

84. Beldman G, Vincken JP, Schols HA, Meeuwsen PJA, Herweijer M, Voragen AGJ (2003) Biocatal Biotransformation 21(4): 189

85. De Vries JA, Rombouts FM, Voragen AGJ, Pilnik W (1983) Carbohydr Polym 3:245

86. Morris ER, Powell DA, Gidley MJ, Rees DA (1982) J Mol Biol 155(4):507

87. Braccini I, Grasso RP, Perez S (1990) Carbohydr Res 317(1-4): 119

88. Kohn R (1975) Pure Appl Chem 42(3):371

89. Powell DA, Morris ER, Gidley MJ, Rees DA (1982) J Mol Biol 155(4):517

90. Guillon F, Thibault JF (1989) Carbohydr Res 190(1):85

91. Guillon F, Thibault JF, Rombouts FM, Voragen AGJ, Pilnik W (1989) Carbohydr Res 190(1):97

92. Ralet MC, Thibault JF, Faulds CB, Williamson G (2005) Carbohydr Res 263(2):227
93. Rombouts FM, Thibault JF (1986) In: Fishman ML, Chen JJ (eds) ACS Symposium Series. American Chemical Society, Washington, DC, 1986, pp 49-60

94. Waldron KW, Ng A, Parr AJ (1970) J Sci Food Agric 74(2):221

95. Lamport DTA (1970) Annu Rev Plant Physiol 21:235

96. Brown JA, Fry SC (1993) Plant Physiol 103(3):993

97. Gelineo-Albersheim I, Darvill A, Albersheim P (2001) Structural studies of pectin. 9th International Cell Wall Meeting; Toulouse, France, p 183

98. Henrissat B, Coutinho PM, Davies GJ (2001) Plant Mol Biol 47(1):55

99. Morell S, Baur L, Link KP (1934) J Biol Chem 105:1

100. Talmadge KW, Keegstra K, Bauer WD, Albersheim P (1973) Plant Physiol 51(1):158

101. Zhan D, Janssen P, Mort AJ (1998) Carbohydr Res 308:373

102. Yapo BM, Lerouge P, Thibault JF, Ralet MC (2007) Carbohydr Polym 69(3):426

103. Bush M, Marry M, Huxham M, Jarvis M, McCann M (2001) Planta 213(6):869

104. Bush MS, McCann MC (1999) Physiol Plant 107(2):201

105. Oomen RJFJ, Vincken JP, Bush MS, Skjøt M, Doeswijk-Voragen CHL, Ulvskov P, Voragen AGJ, McCann MC, Visser RGF (2003) In: Voragen AGJ, Schols HA, Visser RGF (eds) Advances in pectin and pectinase research. Kluwer Academic Publishers, Dordrecht, pp 15-35

106. Willats WGT, McCartney L, Mackie W, Knox JP (2001) Plant Mol Biol 47(1):9

107. Aspinall GO, Gestetner B, Molloy JA, Uddin M (1968) J Chem Soc (C) 2554

108. Schols HA, Vierhuis E, Bakx EJ, Voragen AGJ (1995) Carbohydr Res 275(2):343

109. Huisman MMH, Schols HA, Voragen AGJ (2003) In: Voragen AGJ, Schols HA, Visser RGF (eds) Advances in pectin and pectinase research. Kluwer Academic Publishers, Dordrecht, pp $159-168$

110. Voragen AGJ, Beldman G, Schols H (2001) In: McCleary BV, Prosky L (eds) Advanced dietary fibre technology. Blackwell Science, Oxford, pp 379-397

111. Gao QP, Kiyohara H, Yamada H (1990) Carbohydr Res 196:111

112. Aspinall GO, Hunt K, Morrison IM (1967) J Chem Soc. Perkin Trans 111:1080

113. Mort AJ (2002) In: Seymour GB, Knox JP (eds) Pectins and their manipulation. Blackwell Publishing Ltd., Oxford, pp 30-51

114. Voragen AGJ, Schols HA, Gruppen H (1992) In: Meuser F, Manners DJ, Seibel W (eds) Plant polymeric carbohydrates. Royal Society of Chemistry, Berlin, pp 3-20

115. BeMiller JN (1967) Adv Carbohydr Chem 22:25

116. Mort AJ, Komalavilas P, Rorrer GL, Lamport DTA (1989) Modern Meth Plant Anal 10:37

117. Albersheim P, Neukom H, Deuel H (1960) Arch Biochem Biophys 90:46

118. van Buren JP, Pitifer LA (1992) J Food Sci 57(4):1022

119. Saulnier L, Thibault JF (1999) J Sci Food Agric 79(3):396

120. Zhan D, Qiu F, Mort AJ (2001) Carbohydr Res 330(3):357

121. Daas PJH, Meyer-Hansen K, Schols HA, de Ruiter GA, Voragen AGJ (1999) Carbohydr Res 318:135

122. Searle-van Leeuwen MJF, Vincken JP, Schipper D, Voragen AGJ, Beldman G (1995) In: Visser J, Voragen AGJ (eds) Pectins and pectinases. Elsevier Science B.V., Amsterdam, pp 793-798

123. Versteeg C (1979) Pectinesterases from the orange fruit, their purification, general characteristics and juice cloud destabilizing properties. Doctoral Thesis, Wageningen University

124. Bonnin E, Dolo E, Le Goff A, Thibault JF (2002) Carbohydr Res 337(18): 1687 
125. An J, Zhang L, O’Neill MA, Albersheim P, Darvill AG (1994) Carbohydr Res 264(1):83

126. De Vries JA, Rombouts FM, Voragen AGJ, Pilnik W (1982) Carbohydr Polym 2:25

127. Mutter M, Renard CMGC, Beldman G, Schols HA, Voragen AGJ (1998) Carbohydr Res 311(3):155

128. Selvendran RR, Ryden P (1990) In: Dey PM, Harborne JB (eds) Carbohydrates. Academic Press, London, p 540

129. Voragen AGJ, Pilnik W, Thibault JF, Axelos MAV, Renard CMGC (1995) In: Stephen AM (ed) Food polysaccharides and their applications. Marcel Dekker, New York, pp 287-339

130. De Ruiter GA, Schols HA, Voragen AGJ, Rombouts FM (1992) Anal Biochem 207(1):176

131. Englyst HN, Cummings JH (1984) Analyst 109, 937

132. Hakomori SI (1964) J Biochem (Tokyo) 55(2): 205

133. Voragen AGJ, Schols HA, Pilnik W (1986) Food Hydrocolloids $1(1): 65$

134. Schols HA, Voragen AGJ (2002) In: Seymour GB, Knox JP (eds) Pectins and their manipulation. Blackwell Publishing Ltd., London, pp 1-15
135. Lee YC (1996) J Chromatogr A 720(1-2):137

136. Daas PJH, Arisz PW, Schols HA, de Ruiter GA, Voragen AGJ (1998) Anal Biochem 257:195

137. Mort AJ, Chen EMW (1996) Electrophoresis 17(2):379

138. Zhang Z, Pierce ML, Mort AJ (1996) Electrophoresis 17(2):372

139. Kabel MA, Schols HA, Voragen AGJ (2001) Carbohydr Polym 44(2): 161

140. van Alebeek G, Zabotina O, Beldman G, Schols HA, Voragen AGJ (2000) J Mass Spectrom 35(7):831

141. Quemener B, Pino JCC, Ralet MC, Bonnin E, Thibault JF (2003) J Mass Spectrom 38(6):641

142. Hilz H (2007) Characterization of cell wall polysaccharides in billberries and black currants. Doctoral Thesis, Wageningen University

143. Nunan KJ, Sims IM, Bacic A, Robinson SP, Fincher GB (1997) Planta 203(1):93

144. Ralet MC, Andre-Leroux G, Quemener B, Thibault JF (2005) Phytochemistry 66(24):2800 